\title{
Uranium in the Arabian Sea: role of denitrification in controlling its distribution
}

\section{Rôle de la dénitrification dans le contrôle de la distribution d'uranium en mer d'Arabie}

\author{
R. Rengarajan *, M.M. Sarin, S. Krishnaswami \\ Planetary and Geosciences Division, Physical Research Laboratory, Ahmedabad 380 009, India \\ Received 26 March 2003; revised and accepted 27 May 2003
}

\begin{abstract}
A total of 61 samples, from six vertical profiles between surface and $1800 \mathrm{~m}$ from the Arabian Sea, have been analysed for uranium concentration to assess its behaviour in oxic and sub-oxic waters. These samples cover a wide range of dissolved oxygen concentration, from 0.14 to $230 \mu \mathrm{M}$. Uranium concentration in most of the samples fall in the range of $3.2 \pm 0.2 \mu \mathrm{g}{ }^{-1}$. In general, uranium exhibits a conservative behaviour in the Arabian Sea water column and denitrification processes do not seem to influence its abundance. The mean uranium/salinity ratio in waters with dissolved oxygen $<2 \mu \mathrm{M}$ is $(9.17 \pm 0.15) \times 10^{-8} \mathrm{~g} \mathrm{~g}^{-1}$, nearly identical to the ratio $(9.22 \pm 0.27) \times 10^{-8} \mathrm{~g} \mathrm{~g}^{-1}$ in waters with dissolved oxygen $>100 \mu \mathrm{M}$, and in waters from other oceanic regions $(9.34 \pm 0.56) \times 10^{-8} \mathrm{~g} \mathrm{~g}^{-1}$. In one of the profiles $\left(18^{\circ} \mathrm{N}, 64^{\circ} \mathrm{E}\right)$ collected during summer monsoon (SK115/6; August 1996), two samples from 300 and $600 \mathrm{~m}$ have uranium concentration $\sim 10-15 \%$ lower than that expected based on salinity. Further studies are needed to confirm these results and to characterize the process(es) contributing to depletion of uranium at these depths.
\end{abstract}

(C) 2003 Éditions scientifiques et médicales Elsevier SAS and Ifremer/CNRS/IRD. All rights reserved.

\section{Résumé}

La teneur en uranium de soixante et un échantillons provenant de six profils verticaux entre la surface et $1800 \mathrm{~m}$ à l'ouest de la mer d'Arabie a été analysée de manière à examiner son comportement en zone oxygénée et en zone anoxique, couvrant une large gamme de concentrations en oxygène (de 0,14 à $230 \mu \mathrm{M})$. La concentration en uranium est proche de $3,2 \pm 0,2 \mu \mathrm{g} 1^{-1}$ dans la plupart des échantillons. Généralement, l'uranium présente une évolution conservative dans la colonne d'eau et les processus de dénitrification ne paraissent pas l'influencer. Le rapport uranium/salinité dans les eaux où la teneur en oxygène est inférieure à $2 \mu \mathrm{M}$ est de $(9,17 \pm 0,15) \times 10^{-8} \mathrm{~g}^{-1}$. Elle est voisine dans les eaux où la teneur en oxygène dépasse $100 \mu \mathrm{M}$ ainsi que dans les eaux océaniques où elle atteint $(9,34 \pm 0,56) \times 10^{-8} \mathrm{~g}^{-1}$. Sur un des profils $\left(18^{\circ}\right.$ $\mathrm{N}, 54^{\circ} \mathrm{E}$ ) récolté durant la mousson d'été, deux échantillons de 300 et $600 \mathrm{~m}$ présentent des concentrations en uranium d'environ 10 à $15 \%$ inférieures à celles qui sont attendues d'après la salinité. Des études complémentaires sont nécessaires pour confirmer ces résultats et pour caractériser le (les) processus contribuant à la disparition de l'uranium à ces profondeurs.

C 2003 Éditions scientifiques et médicales Elsevier SAS and Ifremer/CNRS/IRD. All rights reserved.

Keywords: Arabian Sea; Uranium; Denitrification; Sub-oxic layers

Mots clés : Mer d'Arabie ; Uranium ; Dénitrification ; Niveaux faiblement oxygénés

\section{Introduction}

Studies on the marine geochemistry of uranium, particularly the pathways of its removal from seawater, have been a

\footnotetext{
* Corresponding author.

E-mail address: rajan@prl.ernet.in (R. Rengarajan).
}

topic of detailed research during the recent past (Zheng et al., 2002a, b). In seawater, uranium exists as a stable, soluble, uranyl-carbonate complex $\left(\mathrm{UO}_{2}\left(\mathrm{CO}_{3}\right)_{3}{ }^{4-}\right)$. Initial studies on uranium abundance in shelf and anoxic marine sediments have led to propose that reduction of soluble U(VI) to more particle reactive $\mathrm{U}(\mathrm{IV})$ could be a mechanism contributing to 
its removal from the water column (see for example, Veeh, 1967; Huh et al., 1987). This hypothesis was extended (Veeh, 1967) to suggest that large-scale removal of uranium from seawater could occur, not only in reducing shelf regions but also in hemipelagic areas, where high biological productivity can cause hypoxic/anoxic conditions and a shift in the uranium oxidation state. Subsequent studies on the behaviour of uranium have generally attested the role of shelf and margin sediments as a sink for oceanic uranium (Barnes and Cochran, 1990; Klinkhammer and Palmer, 1991; Swarzenski et al., 1999). These studies led to the conclusion that the dominant mechanism of uranium removal from seawater is diffusion of U(VI) from bottom waters to anoxic regions of sediments where it is reduced to U(IV) and trapped. The removal of uranium around the oxic-anoxic boundary in sediments results in a concentration gradient in pore waters and acts as a "pump" to transfer uranium from oxic bottom water to sediments (Anderson et al., 1989; Thompson et al., 1990). The presence of non-lithogenic uranium in settling particulate matter in the oceans (Anderson, 1982; Anderson et al., 1989; Zheng et al., 2002b), however, hints at other pathways of its removal such as biological uptake and chemical/biogeochemical interactions with settling particulate matter. Quantitative significance of these mechanisms for the removal of uranium from seawater and its marine budget depends on the behaviour of non-lithogenic uranium, during its transit through the water column.

Anderson (1987) and Anderson et al. (1989) investigated the redox chemistry of $U$ in two anoxic marine basins, namely the Black Sea and Cariaco Trench, to further examine processes of uranium removal from seawater. In both these basins, almost all dissolved uranium was found in the U(VI) oxidation state, though physico-chemical considerations (long residence times and presence of sulphide) would favour a valence shift from U(VI) to U(IV) in both these basins. Similar results were also observed in the sulphidic waters of Framvaren Fjord (Norway) and in the seasonally anoxic Saanich Inlet, Canada (McKee and Todd, 1993). These results argue against rapid reduction of U(VI) in anoxic seawater and hence its removal from the water column through such a mechanism. This led to the suggestion that sequestering of seawater uranium by anoxic sediments is the primary pathway for its removal from these basins (Anderson et al., 1989; Zheng et al., 2002b). These results also brought out the role of mineral surfaces in accelerating the kinetics of U(VI) reduction to $\mathrm{U}(\mathrm{IV})$ in the sea.

The Arabian Sea, because of its characteristic chemical and biological properties, is an interesting basin to study the geochemical behaviour of uranium. One of the peculiar properties of the Arabian Sea is the semi-annual reversal of wind regimes caused by the monsoon. These reversals have significant impact on the upper ocean circulation and biological productivity of the region (Qasim, 1982; Madhupratap et al., 1996). The structure of the upper layers of the Arabian Sea (Shetye et al., 1994; Prasanna Kumar and Prasad, 1999) is dictated by the transport and mixing of the Arabian Sea high salinity water (ASHW, $\sigma_{\theta}=22.8-24.5$ ), Persian Gulf water (PGW, $\sigma_{\theta}=26.2-26.8$ ) and the Red Sea water (RSW, $\left.\sigma_{\theta}=27.0-27.4\right)$. Some of the biogenic particles produced in surface water settle to the interior where they are remineralised. These biogeochemical processes coupled with restricted ventilation contribute to extreme depletion of oxygen in the intermediate waters (100-1200 m depth). This generates a widespread oxygen minimum zone (OMZ) with active denitrification (Naqvi, 1991, 1994) in the intermediate waters. The redox conditions prevailing in the intermediate waters of the Arabian Sea significantly influence the distribution of elements such as Fe, Mn and a suite of others in them (Saager, 1994). Another characteristic of the Arabian Sea waters is the supersaturation of $\mathrm{CH}_{4}$ in the water column, which has been explained in terms of likely occurrence of reducing microenvironments (Owens et al., 1991; Jayakumar et al., 2001). Although there is no dissolved $\mathrm{H}_{2} \mathrm{~S}$ in the intermediate waters, the presence of sulphides as metal complexes has been reported (Theberge et al., 1997).

The chemical composition of sediments also shows the impact of reducing conditions. Unlike the water column, sediments from many areas of the Arabian Sea are characterized by presence of $\mathrm{H}_{2} \mathrm{~S}$. Low $\mathrm{Mn}$ and high uranium concentrations characterize many of these sediments. Moderate to high concentrations of authigenic uranium in margin sediments makes this basin one of the potential sites for removal of U from seawater (Borole et al., 1982; Sarkar et al., 1993; Somayajulu et al., 1994; Nagender Nath et al., 1997; Pailler et al., 2002). Based on the study of uranium distribution in a sediment core in the southeastern Arabian Sea, Sarkar et al. (1993) had inferred that anoxic conditions prevailed in this region during the last glacial period.

Thus, the interplay between wind patterns, water circulation and surface productivity makes the Arabian Sea an ideal basin to study the geochemical behaviour of elements especially those which are sensitive to changes in redox conditions (Saager, 1994). The unique properties of the Arabian Sea, viz. oxic surface water, sub-oxic intermediate water (environments that experience denitrification but no hydrogen sulphide production are referred to as "sub-oxic", Naqvi, 1994), high particulate flux through the water column (Ramaswamy and Nair, 1994), have led us to investigate the abundance and distribution of uranium in the water column to obtain a better understanding of its geochemistry in regions of changing redox and high particulate flux. Further, such a study would help to constrain the impact of anaerobic respiration (denitrification) in influencing the marine geochemistry of uranium.

\section{Sampling and analytical methods}

The sampling strategy was designed to assess the behaviour of dissolved uranium in oxic and sub-oxic waters during different seasons. Towards this, vertical profiles of water samples, spanning oxic and sub-oxic layers were collected during intermonsoon and SW monsoon periods. The sam- 


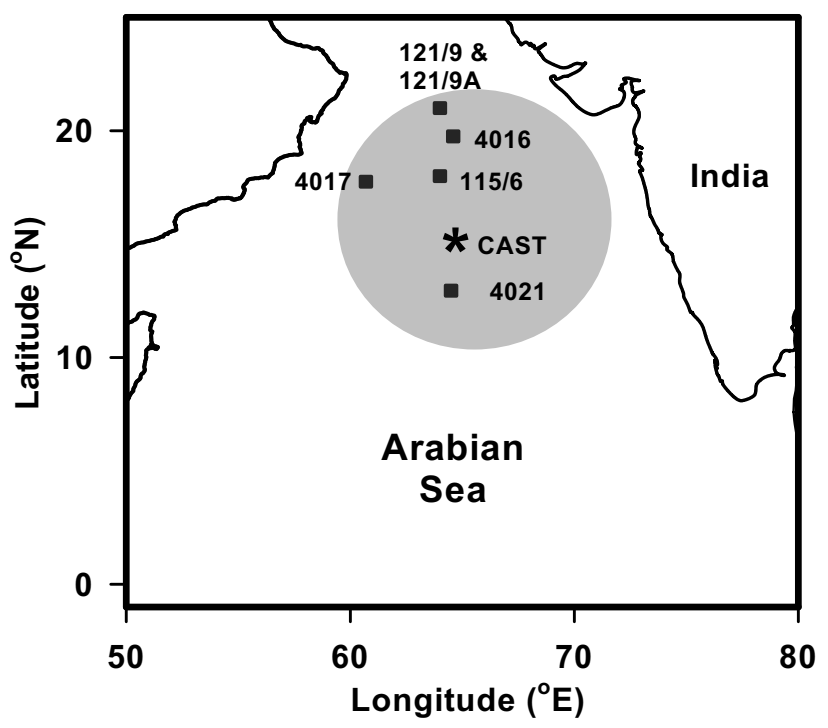

Fig. 1. Location map of seawater profiles (squares) collected for uranium measurements. Grey circle marks the region of intense denitrification (Naqvi, 1991). Location of the sediment trap sample (CAST) deployed at $3000 \mathrm{~m}$ depth is indicated as * (Ramaswamy and Nair, 1994).

pling was done mainly along $64^{\circ} \mathrm{E}$ transact, between $21^{\circ} \mathrm{N}$ and $10^{\circ} \mathrm{N}$ and a profile from the western Arabian Sea (Fig. 1). A total of 61 samples from six vertical profiles (depths ranging from surface to $1800 \mathrm{~m}$ ) were collected for uranium concentration measurements. These collections were made during three cruises, two of them, SK115 (August 1996, SW monsoon) and SK121 (February 1997, end of NE monsoon) were conducted onboard ORV Sagar Kanya, as a part of the Indian JGOFS programme. The third cruise, SS164 (March 1998), was carried out onboard FORV Sagar Sampada. Two of the profiles, SK121/9 and SK121/9A were collected $5 \mathrm{~d}$ apart from very nearby locations $\left(21^{\circ} \mathrm{N}, 64^{\circ} \mathrm{E}\right)$, surface waters of these profiles were characterized by intense salp bloom, Pagea Confederata, during the sampling period (Prasanna Kumar et al., 2001a).

Water samples for uranium measurements were collected using $301 \mathrm{GoFlo}$ bottles. The sampling depths for uranium measurements were based on salinity/temperature and dissolved oxygen profiles, measured using a Seabird CTD system. During SS164 cruise, dissolved oxygen was determined following JGOFS protocol (SCOR, 1996). For uranium, 4-5 1 of seawater was transferred from the GoFlo bottles, soon after collection to clean polypropylene containers and was acidified with concentrated $\mathrm{HNO}_{3}$ to $\mathrm{pH} \sim 2$. This was followed by addition of $\sim 100 \mathrm{mg}$ of Fe carrier (as $\mathrm{FeCl}_{3}$ ) and ${ }^{232} \mathrm{U}$ tracer $\left(0.5 \mathrm{ml}\right.$ of $\left.9.0 \pm 0.16 \mathrm{dpm} \mathrm{ml}^{-1}\right)$. The solution was continuously stirred and purged with compressed air to break the uranyl carbonate complex and also to establish tracer equilibrium with seawater uranium. After 3-4 h, the $\mathrm{pH}$ was adjusted to 8 by adding concentrated $\mathrm{NH}_{4} \mathrm{OH}$ and uranium was co-precipitated with $\mathrm{Fe}(\mathrm{OH})_{3}$. The uranium from ferric hydroxide precipitate was separated, purified and assayed by alpha spectrometry following procedures of Sarin et al. (1992).

\section{Results and discussion}

The uranium concentration of the samples along with the salinity and dissolved oxygen data are listed in Table 1 , the errors are $\pm 1 \sigma$ standard deviation derived from counting statistics and uncertainties in ${ }^{232} \mathrm{U}$ spike calibration. Average $\pm 1 \sigma$ uncertainty in measurements is $\pm 2.6 \%$. Therefore, differences in uranium concentration between samples in excess of $\sim 6 \%$ can be measured reliably using the techniques used in this study. The uranium concentration versus depth in SK121/9 and SK121/9A, the two nearby profiles, are in good agreement (Table 1) attesting to the overall reliability of the data. The samples analysed cover a wide range of dissolved oxygen concentration, from 0.14 to $230 \mu \mathrm{M}$, with active denitrification. Although uranium concentrations in the samples show a significant range, from 2.78 to $3.62 \mu \mathrm{g}$ $1^{-1}, 52$ of the 61 samples have values within a narrow range, $3.2 \pm 0.2 \mu \mathrm{g}^{-1}$ covering a salinity of 34.8919-36.5048 (Table 1). The two lowest uranium concentration values $\left(2.78 \pm 0.10\right.$ and $\left.2.95 \pm 0.08 \mu \mathrm{g} \mathrm{l^{-1 }}\right)$ are from the SK$115 / 6$ profile collected during SW monsoon; these results will be discussed later. Regression analysis of data shows an overall increase in uranium concentration within the salinity range sampled (Fig. 2), consistent with that reported earlier for the Arabian Sea and other oceanic regions (Ku et al., 1977; Sarin et al., 1992, 1994). The mean ${ }^{234} \mathrm{U} /{ }^{238} \mathrm{U}$ activity ratio of the samples is $1.14 \pm 0.02(n=61)$ quite similar to those reported for other oceanic regions (op. cit.).

The distribution of uranium with depth in the six profiles analysed along with a typical dissolved oxygen profile of the region is shown in Fig. 3. The data show that, within uncertainties of measurements, the uranium concentrations are nearly uniform with depth and are independent of dissolved oxygen concentration. This conclusion is also borne out from the distribution of the U/salinity ratios in waters with various levels of dissolved oxygen concentrations (Table 2, Fig. 4). The mean U/salinity ratio (Table 2 ) in samples with dissolved oxygen in the range of $0.14-2 \mu \mathrm{M}(n=14)$ is $(9.17 \pm 0.15) \times$ $10^{-8} \mathrm{~g} \mathrm{~g}^{-1}$, nearly identical to the ratio $(9.22 \pm 0.27) \times 10^{-8} \mathrm{~g}$ $\mathrm{g}^{-1}$ in samples with dissolved oxygen $>100 \mu \mathrm{M}$. In fact, the samples from all the six profiles with dissolved oxygen $<5$ $\mu \mathrm{M}(n=34)$, have U/salinity ratio of $(9.10 \pm 0.34) \times 10^{-8} \mathrm{~g}$ $\mathrm{g}^{-1}$, which is the same as the mean ratio for all the samples. The mean U/salinity ratio in samples with dissolved oxygen $<5 \mu \mathrm{M}$ also overlaps with the "global" ratio of $(9.34 \pm 0.56) \times 10^{-8} \mathrm{~g} \mathrm{~g}^{-1}$ (Ku et al., 1977). These results suggest that, in general, there is no measurable change in uranium concentration in the water column of the Arabian Sea during the seasons sampled even if dissolved oxygen levels reach values as low as $0.14 \mu \mathrm{M}$ and in presence of denitrification. Thus, there is neither removal of uranium due to sub-oxic and denitrifying conditions nor addition of uranium resulting from regeneration of biogenic particles in the intermediate waters of the Arabian Sea.

Two samples from SK115/6 profile $\left(18^{\circ} \mathrm{N}, 64^{\circ} \mathrm{E}\right)$ show exception to this general trend in that they have measurably 
Table 1

Uranium concentration in samples collected from the Arabian Sea

\begin{tabular}{|c|c|c|c|}
\hline Depth (m) & Salinity & $\begin{array}{l}\text { Dissolved } \\
\text { oxygen }(\mu \mathrm{M})\end{array}$ & $U\left(\mu \mathrm{g}^{-1}\right)$ \\
\hline \multicolumn{4}{|c|}{ 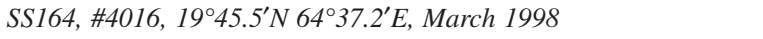 } \\
\hline 101 & 36.3263 & 133 & $3.33 \pm 0.09$ \\
\hline 153 & 36.0109 & 11 & $3.22 \pm 0.08$ \\
\hline 247 & 36.1325 & 0.35 & $3.34 \pm 0.07$ \\
\hline 320 & 36.1258 & 1.3 & $3.3 \pm 0.08$ \\
\hline 378 & 36.0407 & 0.64 & $3.32 \pm 0.09$ \\
\hline 474 & 35.7965 & 0.14 & $3.29 \pm 0.07$ \\
\hline 582 & 35.6961 & 0.55 & $3.36 \pm 0.09$ \\
\hline 700 & 35.6142 & 0.66 & $3.24 \pm 0.09$ \\
\hline 823 & 35.5254 & 2.4 & $3.34 \pm 0.08$ \\
\hline 1008 & 35.3833 & 11 & $3.32 \pm 0.09$ \\
\hline 1275 & 35.1946 & 17 & $3.18 \pm 0.08$ \\
\hline 1785 & 34.9094 & 63 & $3.25 \pm 0.08$ \\
\hline \multicolumn{4}{|c|}{ SS164, \#4017, $17^{\circ} 45.5^{\prime} \mathrm{N} 60^{\circ} 40.9^{\prime} \mathrm{E}$, March 1998} \\
\hline 100 & 36.0643 & 36 & $3.15 \pm 0.09$ \\
\hline 161 & 35.8575 & 0.57 & $3.35 \pm 0.09$ \\
\hline 300 & 35.8806 & 0.56 & $3.28 \pm 0.09$ \\
\hline 400 & 35.7898 & 0.87 & $3.25 \pm 0.08$ \\
\hline 584 & 35.8622 & 3.4 & $3.25 \pm 0.09$ \\
\hline 743 & 35.561 & 1.1 & $3.15 \pm 0.09$ \\
\hline 900 & 35.438 & 2.3 & $3.25 \pm 0.10$ \\
\hline 1207 & 35.1605 & 21 & $3.14 \pm 0.08$ \\
\hline \multicolumn{4}{|c|}{ SS164, \#4021, 12 $57.9^{\prime} \mathrm{N} 64^{\circ} 29^{\prime} \mathrm{E}$, March 1998} \\
\hline 82 & 36.477 & 174 & $3.38 \pm 0.09$ \\
\hline 248 & 35.5897 & 5.0 & $3.22 \pm 0.09$ \\
\hline 349 & 35.4981 & - & $3.2 \pm 0.09$ \\
\hline 429 & 35.4945 & - & $3.28 \pm 0.08$ \\
\hline 498 & 35.4989 & 5.9 & $3.36 \pm 0.09$ \\
\hline 626 & 35.4704 & 6.3 & $3.36 \pm 0.09$ \\
\hline 743 & 35.4082 & 12 & $3.27 \pm 0.08$ \\
\hline 846 & 35.3522 & 15 & $3.27 \pm 0.09$ \\
\hline 1046 & 35.1741 & 27 & $3.16 \pm 0.08$ \\
\hline 1750 & 34.8919 & 83 & $3.34 \pm 0.08$ \\
\hline \multicolumn{4}{|c|}{ SK115/6, $18^{\circ} \mathrm{N} 64^{\circ} \mathrm{E}$, August 1996} \\
\hline 50 & 36.2111 & 201 & $3.26 \pm 0.08$ \\
\hline 200 & 35.8873 & 2 & $3.24 \pm 0.08$ \\
\hline 300 & 35.9643 & 5 & $2.95 \pm 0.08$ \\
\hline 400 & 35.6787 & 5 & $3.27 \pm 0.10$ \\
\hline 500 & 35.7485 & 4 & $3.08 \pm 0.09$ \\
\hline 600 & 35.6673 & 3 & $2.78 \pm 0.10$ \\
\hline 750 & 35.5392 & 7 & $3.13 \pm 0.09$ \\
\hline 1000 & 35.3396 & 10 & $3.22 \pm 0.08$ \\
\hline \multicolumn{4}{|c|}{ SK121/9, $21^{\circ} \mathrm{N} 64^{\circ} \mathrm{E}$, February 1997} \\
\hline 5 & 36.4855 & - & $3.44 \pm 0.09$ \\
\hline 25 & 36.4805 & $230^{\mathrm{a}}$ & $3.39 \pm 0.09$ \\
\hline 50 & 36.4835 & $204^{\mathrm{a}}$ & $3.35 \pm 0.09$ \\
\hline 75 & 36.5567 & 166 & $3.47 \pm 0.08$ \\
\hline 100 & 36.5117 & 23 & $3.62 \pm 0.09$ \\
\hline 150 & 35.9628 & 1.9 & $3.37 \pm 0.08$ \\
\hline 200 & 35.9209 & 2.3 & $3.31 \pm 0.08$ \\
\hline 250 & 36.0171 & 4.6 & $3.33 \pm 0.08$ \\
\hline 300 & 36.007 & 3.5 & $3.42 \pm 0.08$ \\
\hline 350 & 35.8864 & 2.3 & $3.32 \pm 0.08$ \\
\hline 400 & 35.8929 & 2.8 & $3.26 \pm 0.08$ \\
\hline \multicolumn{4}{|c|}{ SK121/9A, $21^{\circ} 05.6^{\prime} \mathrm{N} 63^{\circ} 56.9^{\prime}$ E, February 1997} \\
\hline 5 & 36.3544 & - & $3.34 \pm 0.08$ \\
\hline 25 & 36.357 & $230^{\mathrm{a}}$ & $3.32 \pm 0.07$ \\
\hline
\end{tabular}

\begin{tabular}{llll}
\hline Depth $(\mathrm{m})$ & Salinity & $\begin{array}{l}\text { Dissolved } \\
\text { oxygen }(\mu \mathrm{M})\end{array}$ & $U\left(\mu \mathrm{g} \mathrm{l^{-1 }}\right)$ \\
\hline 50 & 36.4964 & $204^{\mathrm{a}}$ & $3.42 \pm 0.08$ \\
75 & 36.4647 & 166 & $3.41 \pm 0.08$ \\
100 & 36.5048 & 23 & $3.38 \pm 0.08$ \\
150 & 35.8237 & 1.9 & $3.31 \pm 0.08$ \\
200 & 35.9888 & 2.3 & $3.29 \pm 0.09$ \\
250 & 36.1663 & 4.6 & $3.44 \pm 0.08$ \\
300 & 35.9878 & 3.5 & $3.37 \pm 0.08$ \\
350 & 35.9607 & 2.3 & $3.28 \pm 0.08$ \\
400 & 35.7859 & 2.8 & $3.31 \pm 0.08$ \\
1179 & 35.2395 & - & $3.33 \pm 0.08$ \\
\hline \multicolumn{2}{c}{${ }^{a}$ Interpolated values based on measurements in adjacent depths. }
\end{tabular}

${ }^{a}$ Interpolated values based on measurements in adjacent depths.

lower concentration of uranium than that expected based on salinity. These samples, from 300 and $600 \mathrm{~m}$ depths with dissolved oxygen: $\sim 5$ and $3 \mu \mathrm{M}$, respectively, have uranium concentration of $2.95 \pm 0.08$ and $2.78 \pm 0.1 \mu \mathrm{g} \mathrm{l^{-1 }}$ and $\mathrm{U} / \mathrm{salinity}$ ratios of $(8.00 \pm 0.22) \times 10^{-8}$ and $(7.60 \pm 0.27) \times$ $10^{-8} \mathrm{~g} \mathrm{~g}^{-1}$, respectively. These are the lowest uranium concentrations among all the samples analysed in this study and plot significantly below the overall trend with salinity (Fig. 2). The uranium deficit $(\Delta U)$ in these samples [ $\Delta U=\left(U_{\mathrm{e}}-U_{\mathrm{m}}\right)$, where $U_{\mathrm{e}}$ is expected uranium concentration based on salinity $\left(U_{\mathrm{e}}=(U / S) \times S_{\text {sample }} ; U / S\right.$ is the mean $U$ to salinity ratio, $(9.17 \pm 0.31) \times 10^{-8} \mathrm{~g} \mathrm{~g}^{-1}$ and $S_{\text {sample }}$ is the sample salinity) and $U_{\mathrm{m}}$ is the measured uranium concentration] are $0.35 \pm 0.14$ and $0.49 \pm 0.15 \mu \mathrm{g}^{-1}$, respectively. The process(es) contributing to the depletion of uranium from these samples is difficult to characterize as it (i) seems to be transient, observed only in two samples collected during one season and (ii) is only in two discrete depths, samples collected from above, below and in between these two depths have uranium concentrations which overlap within errors

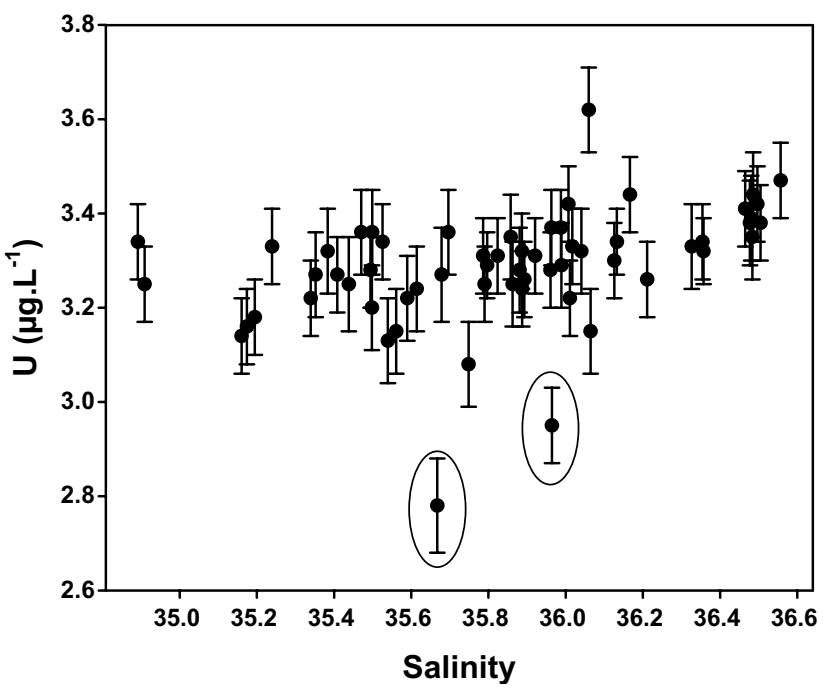

Fig. 2. Plot of uranium vs. salinity in seawater samples collected from the Arabian Sea. Regression analysis of the data shows an overall increase in uranium concentration with salinity. Two of the samples (encircled) that fall significantly lower from the overall trend, are from SK115/6 station. 


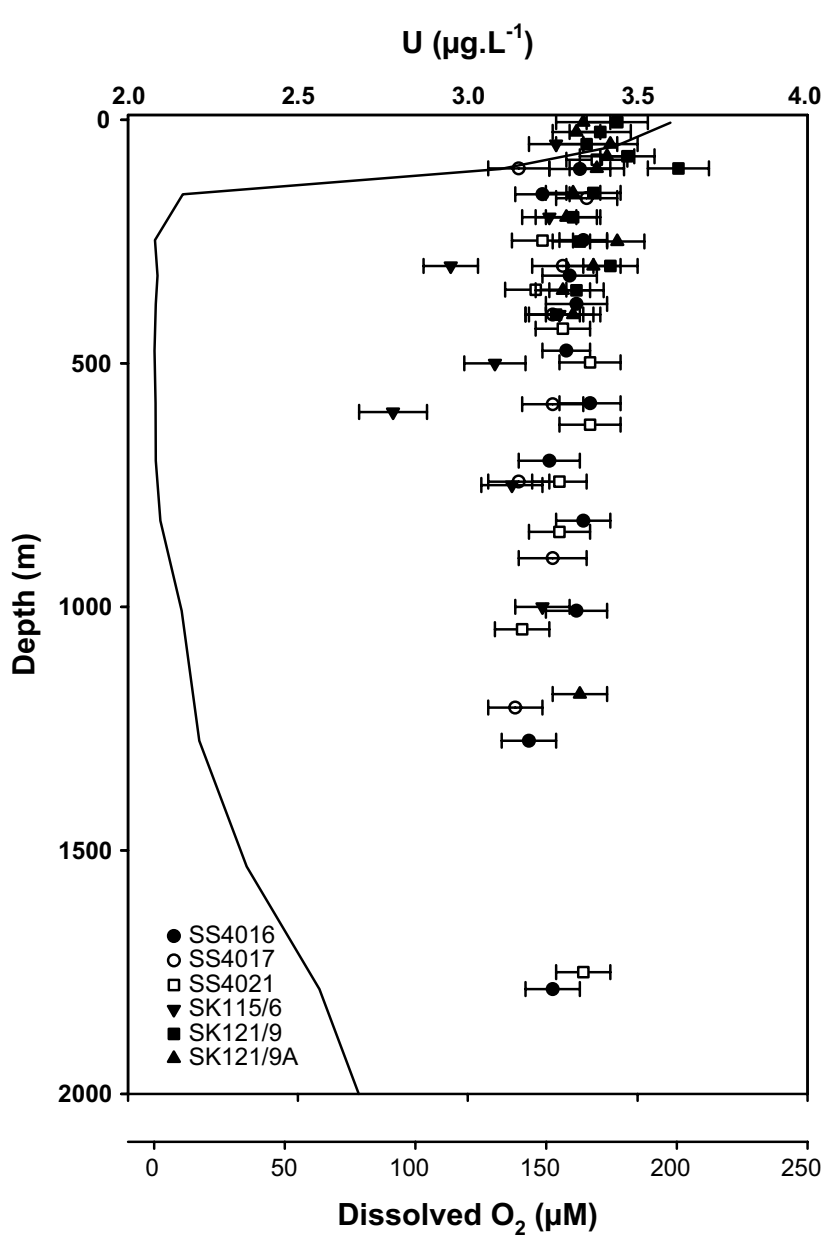

Fig. 3. Uranium concentration vs. depth in profiles collected from the Arabian Sea. Also shown is a typical oxygen profile in the sampling region. Note that though the dissolved oxygen between 200 and $1200 \mathrm{~m}$ is quite low, the uranium concentration is by and large uniform with depth.

with typical oceanic value. It may be argued that the low uranium concentration in these two samples can arise due to measurement artefacts, such as inadequate equilibration between spike and sample uranium. However, this seems unlikely considering that uranium profiles in two adjacent stations collected a few days apart show good agreement (Sta. SK121/9 and SK121/9A, Table 1). These samples are from a profile which was collected during SW monsoon, a period of relatively higher biological productivity and particle rain through the water column. During the sampling period, $\mathrm{Au}-$ gust 1996, the column productivity for this profile was

Table 2

U/salinity ratio in seawater samples of the Arabian Sea with different dissolved oxygen concentration

\begin{tabular}{lll}
\hline Dissolved oxygen & $n$ & U/salinity $\left(10^{-8} \mathrm{~g} \mathrm{~g}^{-1}\right)$ \\
\hline$<2 \mu \mathrm{M}$ & 14 & $9.17 \pm 0.15$ \\
$<5 \mu \mathrm{M}$ & 34 & $9.10 \pm 0.34$ \\
$>100 \mu \mathrm{M}$ & 9 & $9.22 \pm 0.27$ \\
$0.14-230 \mu \mathrm{M}$ & 61 & $9.17 \pm 0.31$ \\
Global average $^{\text {a }}$ & & $9.34 \pm 0.56$
\end{tabular}

${ }^{\text {a }}$ From Ku et al. (1977). $\sim 1000 \mathrm{mg} \mathrm{C} \mathrm{m}^{-2} \mathrm{~d}^{-1}$ (Prasanna Kumar et al., 2001b). Studies on temporal variations in particulate flux at $\sim 3000 \mathrm{~m}$ in the Arabian seawater column from a location $\left(14^{\circ} 30^{\prime} \mathrm{N}\right.$, $\left.64^{\circ} 45^{\prime} \mathrm{E}\right)$ near to SK115/6 profile show higher total particulate and carbon fluxes during the monsoon season (Ramaswamy and Nair, 1994). It is difficult to explain uranium removal at two discrete, intermediate depths by particle settling from surface. The other options would be to invoke advective transport of uranium depleted waters or occurrence of particle layers at these depths, which can facilitate uranium removal. Evidence for the presence of secondary particle maximum or intermediate nepheloid layers has been reported near the top of the OMZ in the Arabian Sea (Naqvi, 1994; Morrison et al., 1999). Bacterial activities have been suggested as the cause for these particle abundance peaks in the intermediate waters. The role of these particles in sequestering dissolved uranium from waters and its removal can only be assessed when measurements of uranium concentration in suspended and settling particles from these depths become available.

The results of this study show that anoxic respiration (denitrification) does not remove detectable amounts of uranium from the intermediate waters of the Arabian Sea and that the biogeochemical processes associated with denitrification does not influence, to any measurable levels, the water column geochemistry of uranium in these waters.

It is well recognized, from the elevated concentration of authigenic uranium in sediments from various regions of the Arabian Sea (Borole et al., 1982; Sarkar et al., 1993; Somayajulu et al., 1994; Nagender Nath et al., 1997; Sirocko et al., 2000; Balakrishna et al., 2001), that this oceanic region is a sink for seawater uranium. However, processes contributing to the supply of authigenic uranium to sediments of the Arabian Sea are not well understood. Studies from other oceanic regions (Anderson, 1982; Anderson et al, 1989; Zheng et al., 2002b) have demonstrated the presence of non-lithogenic $U$ in settling particulate matter. The fate of particulate non-lithogenic uranium (PNU) is shown to depend on oxygen content of water through which the particles transit. It seems to be better preserved and transported to sediments in regions of low dissolved oxygen, such as the Santa Barbara Basin, where PNU accounts for a substantial part of authigenic uranium (Zheng et al., 2002b). Coupled studies of uranium in dissolved and particulate phases from the oxic and sub-oxic waters of the Arabian Sea should throw more light on the processes contributing to the formation and regeneration of PNU and on the pathways for its removal to the sediments.

\section{Conclusions}

Uranium concentration and ${ }^{234} \mathrm{U} /{ }^{238} \mathrm{U}$ isotopic composition of seawater collected from oxic and sub-oxic regions of the Arabian Sea show that, in general, uranium behaves conservatively in these regions. The mean U/salinity ratio in waters with dissolved oxygen $<2 \mu \mathrm{M}$ is $(9.17 \pm 0.15) \times 10^{-8} \mathrm{~g}$ 


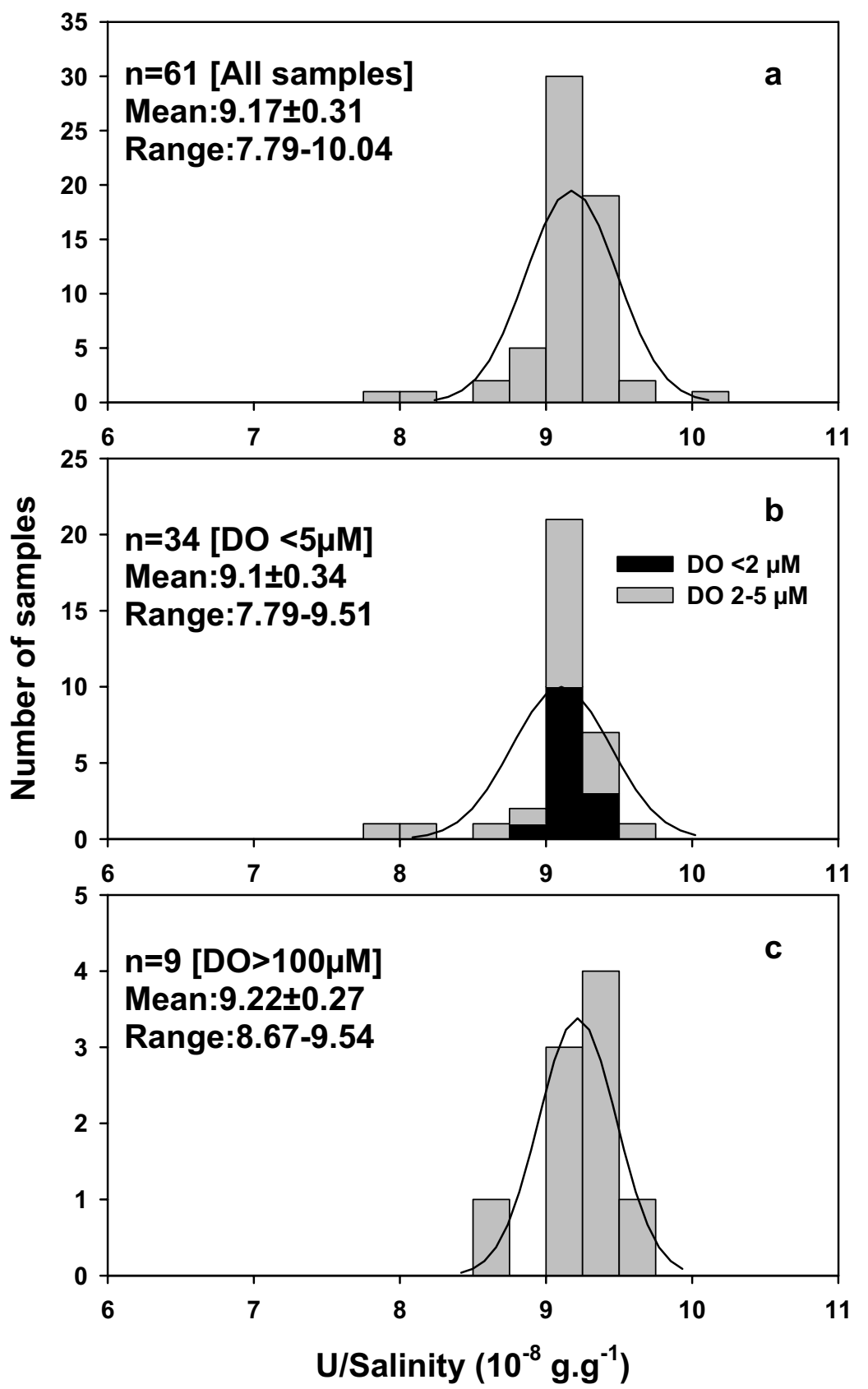

Fig. 4. Frequency diagrams of U/salinity ratios in the (a) all samples (b) waters with dissolved oxygen $<5 \mu \mathrm{M}$ and (c) waters with dissolved oxygen $>100 \mu \mathrm{M}$. Note that the mean U/salinity in all the three sets are nearly identical, indicating the lack of removal of uranium even from sub-oxic waters. For samples with dissolved oxygen $<2 \mu \mathrm{M}$, shown in black in (b), the mean U/salinity ratio is $(9.17 \pm 0.15) \times 10^{-8} \mathrm{~g} \mathrm{~g}^{-1}$.

$\mathrm{g}^{-1}$, nearly identical to the ratio $(9.22 \pm 0.27) \times 10^{-8} \mathrm{~g} \mathrm{~g}^{-1}$ in waters with dissolved oxygen $>100 \mu \mathrm{M}$. Two samples from 300 and $600 \mathrm{~m}$ of one profile $\left(18^{\circ} \mathrm{N}, 64^{\circ} \mathrm{E}\right)$ collected during summer monsoon (SK115/6; August 1996) have 10-15\% lower uranium than that expected based on salinity. The cause for uranium depletion in these two samples is unclear and needs confirmation. A coordinated study of uranium in dissolved and particulate phases along with particle abundances and their composition in the water column should provide better understanding of the geochemical behaviour of uranium in the Arabian Sea.

\section{Acknowledgements}

The samples were collected from two cruises onboard ORV Sagar Kanya during JGOFS (India) programme and a third, onboard FORV Sagar Sampada. We thank Department of Ocean Development, New Delhi for financial support and the crew of these research vessels for help during sampling. We thank Mr. A. Dube for the analytical support during the SS164 cruise, Dr Dileep Kumar, NOA, Goa for providing oxygen data for some of the profiles and an anonymous reviewer for critical comments. 


\section{References}

Anderson, R.F., 1982. Concentration, vertical flux and remineralization of particulate uranium in seawater. Geochim. Cosmochim. Acta 46, 1293 1299.

Anderson, R.F., 1987. Redox behavior of uranium in an anoxic marine basin. Uranium 3, 145-164.

Anderson, R.F., Fleisher, M.Q., LeHuray, A.P., 1989. Concentration, oxidation state, and particulate flux of uranium in the Black Sea. Geochim. Cosmochim. Acta 53, 2215-2224.

Balakrishna, K., Shankar, R., Sarin, M.M., Manjunatha, B.R., 2001. Distribution of U-Th nuclides in the riverine and coastal environments of the tropical southwest coast of India. J. Environ. Radioact. 57, 21-33.

Barnes, C.E., Cochran, J.K., 1990. Uranium removal in oceanic sediments and the oceanic U balance. Earth Planet. Sci. Lett. 97, 94-101.

Borole, D.V., Krishnaswami, S., Somayajulu, B.L.K., 1982. Uranium isotopes in rivers, estuaries and adjacent coastal sediments of western India: their weathering, transport and oceanic budget. Geochim. Cosmochim. Acta 46, 125-137.

Huh, C.-A., Zahnle, D.L., Small, L.F., Noshkin, V.E., 1987. Budgets and behaviors of uranium and thorium isotopes in Santa Monica Basin sediments. Geochim. Cosmochim. Acta 51, 1743-1754.

Jayakumar, D.A., Naqvi, S.W.A., Narvekar, P.V., George, M.D., 2001. Methane in coastal and offshore waters of the Arabian Sea. Mar. Chem. $74,1-13$.

Klinkhammer, G.P., Palmer, M.R., 1991. Uranium in the oceans: where it goes and why? Geochim. Cosmochim. Acta 55, 1799-1806.

Ku, T.L., Knauss, K.G., Mathieu, G.G., 1977. Uranium in the open ocean: concentration and isotopic composition. Deep-Sea Res. 24, 1005-1017.

Madhupratap, M., Prasanna Kumar, S., Bhattathiri, P.M.A., Dileep Kumar, M., Raghukumar, S., Nair, K.K.C., Ramaiah, N., 1996. Mechanism of the biological response to winter cooling in the northeastern Arabian Sea. Nature 384, 549-552.

McKee, B.A., Todd, J.F., 1993. Uranium behavior in a permanently anoxic fjord: microbial control? Limnol. Oceanogr. 38, 408-414.

Morrison, J.M., Codispoti, L.A., Smith, S.L., Wishner, K., Flagg, C., Gardner, W.D., Gaurin, S., Naqvi, S.W.A., Manghnani, V., Prosperie, L., Gundersen, J.S., 1999. The oxygen minimum zone in the Arabian Sea during 1995. Deep-Sea Res. II 46, 1903-1931.

Nath, B.N., Bau, M., Rao, B.R., Rao, C.M., 1997. Trace and rare earth elemental variation in Arabian Sea sediments through a transect across the oxygen minimum zone. Geochim. Cosmochim. Acta 61, 2375-2388.

Naqvi, S.W.A., 1991. Geographical extent of denitrification in the Arabian Sea in relation to some physical processes. Oceanol. Acta 14, 281-290.

Naqvi, S.W.A., 1994. Denitrification processes in the Arabian Sea. Proc. Ind. Acad. Sci. 103, 181-202 (Earth Planet. Sci.).

Owens, N.J.P., Law, C.S., Mantoura, R.F.C., Burkill, P., Llewellyn, C.A., 1991. Methane flux to the atmosphere from the Arabian Sea. Nature 354, 293-296.

Pailler, D., Bard, E., Rostek, F., Zheng, Y., Mortlock, R., Van Geen, A., 2002. Burial of redox-sensitive metals and organic matter in the equatorial Indian Ocean linked to precession. Geochim. Cosmochim. Acta 66, 849-865.

Prasanna Kumar, S., Prasad, T.G., 1999. Formation and spreading of Arabian Sea high-salinity water mass. J. Geophys. Res. 104, 1455-1464.
Prasanna Kumar, S., Madhupratap, M., Dileep Kumar, M., Muraleedharan, P.M., Sawant, S., Gauns, M., de Sousa, S.N., Sarma, V.V.S.S., 2001a. High biological productivity in the central Arabian Sea during summer monsoon driven by Ekman pumping and lateral advection. Curr. Sci. 81, 1633-1638.

Prasanna Kumar, S., Ramaiah, N., Gauns, M., Sarma, V.V.S.S., Muraleedharan, P.M., Raghukumar, S., Dileep Kumar, M., Madhupratap, M., 2001 b. Physical forcing of biological productivity in the Northern Arabian Sea during the Northeast Monsoon. Deep-Sea Res. II 48, 1115-1126.

Qasim, S.Z., 1982. Oceanography of the northern Arabian Sea. Deep-Sea Res. 29, 1041-1068.

Ramaswamy, V., Nair, R.R., 1994. Fluxes of material in the Arabian Sea and Bay of Bengal—sediment trap studies. Proc. Ind. Acad. Sci. 103, 91-112 (Earth Planet. Sci.).

Saager, P.M., 1994. The biogeochemical distribution of trace elements in the Indian Ocean. Proc. Ind. Acad. Sci. 103, 139-180 (Earth Planet. Sci.).

Sarin, M.M., Bhushan, R., Rengarajan, R., Yadav, D.N., 1992. Simultaneous determination of ${ }^{238} \mathrm{U}$ series nuclides in waters of Arabian Sea and Bay of Bengal. Indian J. Mar. Sci. 21, 121-127.

Sarin, M.M., Krishnaswami, S., Ramesh, R., Somayajulu, B.L.K., 1994. ${ }^{238} \mathrm{U}$ decay series nuclides in the northeastern Arabian Sea: scavenging rates and cycling processes. Continent. Shelf Res. 14, 251-265.

Sarkar, A., Bhattacharya, S.K., Sarin, M.M., 1993. Geochemical evidence for anoxic deep water in the Arabian Sea during the last glaciation. Geochim. Cosmochim. Acta 57, 1009-1016.

SCOR, 1996. JGOFS Report No. 19. Protocols for the Joint Global Ocean Flux Study (JGOFS) Core Measurements. Scientific Committee on Oceanic Research, Bergen, Norway 170 pp.

Shetye, S.R., Gouveia, A.D., Shenoi, S.S.C., 1994. Circulation and water masses of the Arabian Sea. Proc. Ind. Acad. Sci. 103, 9-25 (Earth Planet. Sci.).

Sirocko, F., Garbe-Schonberg, D., Devey, C., 2000. Processes controlling trace element geochemistry of Arabian Sea sediments during the last 25000 years. Global Planet. Change 26, 217-303.

Somayajulu, B.L.K., Yadav, D.N., Sarin, M.M., 1994. Recent sedimentary records from the Arabian Sea. Proc. Ind. Acad. Sci. 103, 315-327 (Earth Planet. Sci.)

Swarzenski, P.W., McKee, B.A., Skei, J.M., Todd, J.F., 1999. Uranium biogeochemistry across the redox transition zone of a permanently stratified fjord: Framvaren. Norway. Mar. Chem. 67, 181-198.

Theberge, S.M., Luther III, G.W., Farrenkopf, A.M., 1997. On the existence of free and metal complexed sulphide in the Arabian Sea and its oxygen minimum zone. Deep-Sea Res. II 44, 1381-1390.

Thompson, J., Wallace, H.E., Colley, S., Toole, J., 1990. Authigenic uranium in Atlantic sediments of the last glacial stage-a diagenetic phenomenon. Earth Planet. Sci. Lett. 98, 222-232.

Veeh, H.H., 1967. Deposition of uranium from the ocean. Earth Planet. Sci. Lett. 3, 145-150.

Zheng, Y., Anderson, R.F., van Geen, A., Fleisher, M.Q., 2002a. Remobilization of authigenic uranium in marine sediments by bioturbation. Geochim. Cosmochim. Acta 66, 1759-1772.

Zheng, Y., Anderson, R.F., van Geen, A., Fleisher, M.Q., 2002b. Preservation of particulate non-lithogenic uranium in marine sediments. Geochim. Cosmochim. Acta 66, 3085-3092. 